\title{
Cytokine Tissue Levels as Markers of Disease Activity in Pediatric Crohn Disease
}

\author{
MANUEL A. SILVA, JOSÉ MENEZES, SARAH WIZMAN, ROXANNE GENDRON, \\ LUC OLIGNY, AND ERNEST G. SEIDMAN
}

\begin{abstract}
Mucosal Immunology Laboratory. Division of Gastroenterology, Hepatology and Nutrition [M.A.S., S.W., E.G.S.], Laboratory of Immunovirology, Department of Microbiology and Immunology [J.M.], Pediatric Critical Care Division [R.G.], Sainte-Justine Hospital Research Center, Department of Pathology, Sainte-Justine Hospital [L.O.], and Department of Pediatrics [M.A.S., S.W., E.G.S., R.G.], University of Montréal, Montréal, Québec, Canada H3T 1C5
\end{abstract}

\begin{abstract}
The mucosal immune system is overactivated in Crohn disease (CD) and viral infections have been associated with clinical exacerbations. To investigate the potential association between mucosal inflammation and the cytokines involved in the early response to viruses, we analyzed colonic tissue levels of IL-2R $\alpha$, interferon- $\alpha$, and IL-15 in CD. Patients undergoing diagnostic colonoscopy were classified into controls $(n=22)$ and three CD groups based on the histologic severity of inflammation and clinical activity: a) severely active $\mathrm{CD}(n=3)$; b) mild to moderately active $\mathrm{CD}(n=14)$; and c) quiescent $\mathrm{CD}(n=23)$. Rectal biopsies (two per patient) were homogenized and cytokine levels determined by ELISA kits. Statistical analysis was performed by ANOVA with Tukey and Scheffé tests. IL-2R $\alpha$ levels were increased in the active $C D$ group compared with the quiescent CD group: a) $405 \pm 87$, b) $159 \pm 31$, and c) $33 \pm 15$ $\mathrm{pg} / \mathrm{mg}$ DNA $(p<0.001)$. The latter group was similar to controls $(39 \pm 20 \mathrm{pg} / \mathrm{mg}$ DNA). Furthermore, a linear correlation $(r=$
\end{abstract}

\section{ABSTRACT}

0.98 ) between IL-2R $\alpha$ and disease activity (Van Hees index) was observed. IL-15 levels were also higher in active compared with quiescent $\mathrm{CD}$ and controls: a) $0.69 \pm 0.23$ and b) $0.72 \pm 0.31$ versus c) $0.28 \pm 0.21$ and $0.28 \pm 0.14 \mathrm{pg} / \mathrm{mg}$ DNA for controls $(p<0.05)$. Interferon- $\alpha$ levels were undetectable in all samples. Our data suggest that IL-2R $\alpha$ tissue levels correlate with CD activity. IL-15 is also overproduced in inflamed CD tissue. The lack of a parallel elevation of interferon- $\alpha$ does not support a role for viral induction of IL-15 in inflamed CD samples. (Pediatr Res 54: 456-461, 2003)
CD, Crohn disease
IL-2R $\boldsymbol{\alpha}$, IL-2 receptor $\alpha$-chain
IBD, inflammatory bowel disease
IFN- $\boldsymbol{\alpha}$, interferon- $\alpha$

Abbreviations
IBD, encompassing ulcerative colitis (UC) and CD, are chronic idiopathic disorders in which hereditary and environmental factors interact to produce disease (1). The state of activation of the mucosal immune system is augmented and mediates the mucosal inflammatory response (2).

The IL-2R $\alpha$ is well established as a marker of in vivo immune activation (3). IL-2R $\alpha$ is primarily expressed by activated $\mathrm{T}$ cells and macrophages in intestinal lesions of IBD (4). Circulating IL-2R $\alpha$ levels are significantly elevated in UC and CD patients with active disease; decreases are parallel to

Received December 12, 2002; accepted May 20, 2003.

Correspondence: Ernest Seidman, Division of Gastroenterology, Ste. Justine Hospital, 35 5734, 3175 Cote Ste. Catherine Rd., Montréal Quebec, H3T 1C5, Canada; e-mail: ernest.seidman@Umontreal.ca

Supported by a research grant from the Crohn's and Colitis Foundation of Canada (E.G.S., J.M.), by an IBD Research Chair Award from the CIHR/CCFC (E.G.S.), and by Research Fellowship Awards from the Saint-Justine Hospital Research Foundation and the Canadian Association of Gastroenterology/Axcan Pharma (M.S.).

DOI: 10.1203/01.PDR.0000083002.91602.40 clinical improvement, and increases have been reported to predict CD relapses (5-11). IL-2R $\alpha$ levels were particularly high in the most severely inflamed tissue homogenates from IBD colonic biopsies compared with less inflamed and control tissue $(6,12,13)$. However, no significant correlations were observed with clinical activity indices (12).

IL-15 is a pro-inflammatory cytokine that shares many immunologic properties with IL-2 (14). IL-15 mRNA is expressed in a wide variety of tissues and cells, but its protein is mainly produced by monocytes and macrophages (15-19). Increased IL-15 levels have been reported in peripheral blood mononuclear cells (PBMC) in patients with moderate and severely active UC (20). Also, macrophage production of IL-15 in inflamed mucosal specimens from IBD patients is higher than in control and noninflamed tissues (21). Increased protein expression of IL-15 has also been reported in organ culture supernatants of rectal biopsies from IBD patients (22). However, IL-15 was undetectable in colonic mucosa biopsies from severely inflamed tissue in another 
study (23). Thus, the role of IL-15 in the pathogenesis of IBD remains uncertain.

IL-15 is considered a pivotal antiviral cytokine in the clearance of established viral infections $(24,25)$, along with other rapidly secreted cytokines, such as type I interferons (IFN- $\alpha$ and IFN- $\beta)(26,27)$. IL-15 shares common transcriptional control regions with the IFN regulatory factor (IRF-E) and IFN-2 $\alpha$ (28). Viral infections, particularly of the upper respiratory tract, have been proposed as initiators of IBD relapses in children (29). Several studies have reported the detection of cytomegalovirus, Epstein-Barr virus, and human herpes virus 6 in IBD tissue samples (30-33). Although evidence for measles virus infection in CD has also been reported (34), this has not been confirmed by other investigators (35).

To explore the potential correlation between intestinal inflammation and early antiviral cytokines, we analyzed tissue levels of IL-2R $\alpha$, IFN- $\alpha$, and IL-15 in CD colonic mucosa. We found that IL-2R $\alpha$ and IL-15 tissue levels are overexpressed in inflamed CD tissue. Nevertheless, tissue IFN- $\alpha$ levels were undetectable, suggesting that IL-15 induction in inflamed CD tissue occurs independently of viral infections.

\section{MATERIALS AND METHODS}

Patient selection and tissue procurement. Colonic specimens were obtained from consenting patients at the time of colonoscopy for evaluation of gastrointestinal symptoms. Forty pediatric CD patients and 22 controls were included in this study. The average ages for these groups were 13 and $10 \mathrm{y}$, with a range of 9-20 y and 4-17 y, respectively. Forty percent of the CD patients were male, compared with $54 \%$ of the controls. Disease duration for the CD group was $2.2 \mathrm{y}$ on average, with a range of $0-9 \mathrm{y}$. The diagnosis of $\mathrm{CD}$ was made on the basis of established standard clinical, bacteriological, radiologic, endoscopic, and histopathological criteria. Some of the patients were receiving various standard medications at the time of study, including 5-aminosalicylic acid, corticosteroids, and 6-mercaptopurine. Controls included patients undergoing colonoscopy for polyp removal or for the investigation of lower gastrointestinal bleeding. All had normal radiologic, bacteriological, and histopathological results, with the exception of juvenile polyps, when present. An average of eight colonic biopsies were taken for histopathological analysis. Six additional rectal biopsies were obtained for the purposes of the research study. The later specimens were taken from macroscopically diseased areas of the rectal mucosa. If no macroscopic lesions were visible, the rectal specimens were taken randomly. One of these was fixed in formalin for histologic assessment and the five others were promptly transported on ice in Leibovitz L-15 medium (Invitrogen, Carlsbad, CA, U.S.A.) to the laboratory.

Assessment of disease activity. Disease activity for the CD group was assessed using two standard clinical indices: those of Harvey and Bradshaw (36) and Van Hees (37). The severity of inflammation of the eight colonic and of the rectal biopsies taken from each patient was evaluated histologically by light microscopy using 10 and 40 power fields. All slides were scored by an experienced pathologist, who was blinded to the clinical diagnosis. Six histopathological features were as- sessed: acute inflammatory cell infiltration, the presence of crypt abscesses, mucin depletion, surface epithelial integrity, chronic inflammatory cell infiltration, and crypt architectural irregularities $(38,39)$. Each feature was graded on a 4-point scale, corresponding to normal (0), mild (1), moderate (2), and severe (3). The final score was the numerical sum of all the partial scores, yielding four categories: normal with scores from 0 to 3 , mild from 4 to 8 , moderate from 9 to 14 , and severe from 15 to 18 .

Signed informed consent was obtained from all the patients or their legal guardian. The study protocol and consent form were approved by the Institutional Review Board's Ethics Committee of the Sainte-Justine Research Center before initiation of the study.

Biopsy homogenization. Rectal biopsies (four to five per patient) were blotted dry, weighed (range, 6-29 mg), and then frozen at $-80^{\circ} \mathrm{C}$ until used for assay. Two biopsy samples were placed in glass tubes containing $40 \mu \mathrm{L}$ of protease inhibitor cocktail (Complete Protease Inhibitor Cocktail Tablets, Roche Diagnostics, Mannheim, Germany), $1 \mathrm{~mL}$ of MPER mammalian protein extraction reagent (Pierce Chemical, Rockford, IL, U.S.A.) and homogenized for $30 \mathrm{~s}$ in an ice-cold water bath at 22,000 rpm with an IKA ULTRA-TURRAX T25 homogenizer (IKA Works, Inc., Wilmington, NC, U.S.A.). The homogenates were then centrifuged at $13,000 \mathrm{rpm}$ at $4^{\circ} \mathrm{C}$ in a microfuge for $15 \mathrm{~min}$, and the supernatants were then transferred to fresh tubes and frozen at $-80^{\circ} \mathrm{C}$ until assay.

DNA quantitation. Cytokine levels in tissue homogenates were expressed as picogram of protein per milligram of total tissue DNA. Total DNA was determined in triplicate, by fluorometry using a PicoGreen dsDNA quantitation kit (Molecular Probes, Eugene, OR, U.S.A.). The assays were performed in accordance with the manufacturer's instructions. In brief, $5 \mu \mathrm{L}$ of homogenate supernatant was assayed in $2 \mathrm{~mL}$ of kit solution. After 20 and $40 \mathrm{~min}$ of reaction, cuvettes were excited at $480 \mathrm{~nm}$ and fluorescence emission intensity was measured at $520 \mathrm{~nm}$ using a spectrofluorometer. Concentrations in the samples were determined by interpolation from standard curves, which were run concurrently with each assay. The detection limit of the assay was $25 \mathrm{pg} / \mathrm{mL}$ dsDNA.

Cytokine assays. The concentrations of IL-15, IL-2R $\alpha$, and IFN- $\alpha$ were determined in triplicate by ELISA, using commercially available kits ( $\mathrm{R} \& \mathrm{D}$ Systems, Minneapolis, MN, U.S.A.), in accordance with the manufacturer's instructions. Results were read by colorimetry on an automatic 96-well plate reader at a wavelength of $450 \mathrm{~nm}$ for IL-2R $\alpha$ and IFN- $\alpha$. Samples were not diluted for IFN- $\alpha$ assay. For IL-15, results were read by luminometry on an automatic 96-well plate reader. Concentrations in the samples were determined by interpolation from standard curves, which were run concurrently in each plate. The detection limit of the assays was 10 $\mathrm{pg} / \mathrm{mL}$ for IFN- $\alpha$ and IL-2R $\alpha$, and $0.12 \mathrm{pg} / \mathrm{mL}$ for IL- 15 .

Statistical analysis. Data are presented as means \pm SD. Statistical analysis was performed using a one-way ANOVA with Tukey and Scheffé tests to determine significance for multiple comparisons. The Kruskal-Wallis test with Bonferroni post hoc test was used for semiquantitative nonparametric data (Harvey Bradshaw index and pathologic scores). A $p$ value of 
$<0.05$ was considered statistically significant. Statistical analyses were performed using the SPSS 10.0.5 computer program (SPSS Inc., Chicago, IL, U.S.A.).

\section{RESULTS}

Clinical and pathologic profile of CD patients. The $\mathrm{CD}$ patients were divided into three groups, according to clinical and histopathological disease severity (Table 1). Group A was comprised of cases with severe, active disease profiles. All had pancolitis, with a mean Harvey Bradshaw index of 12 (active $=5-13)$, and a Van Hees index of 232 (severe $=210-300)$. The colonic pathologic score was 10 (moderate) and rectal pathologic score 13 (moderate). Group B had a mild to moderate disease profile, with a mean Harvey Bradshaw index of 4 (inactive $=0-4)$, Van Hees index of 198 (moderate $=150$ 210), pathologic score of 5 (mild), and rectal pathologic score of 2 (normal). Group C had quiescent disease, with a mean Harvey Bradshaw index of 4, Van Hees index of 163, pathologic score of 6 (mild), and rectal pathologic score of 2 (normal). Significant statistical differences between group A and the other CD groups were observed for the Harvey Bradshaw index and rectal histopathological scores (Table 1).

The distribution of patients receiving drug therapy in each CD group was also different. In groups A and B, 33\% and 36\% of the patients were receiving medications for their $\mathrm{CD}$ at the time of the study, compared with the $78 \%$ of group $\mathrm{C}(p<0.05$ versus group $\mathrm{B}$ ). This difference is related to the fact that the $67 \%$ of patients in group A and the $57 \%$ in group B were newly diagnosed, hence untreated, compared with only $39 \%$ in group C. Among the cases in group C, the $69 \%$ were receiving prednisone or 5-aminosalicylic acid, compared with only $33 \%$ in group A and $14 \%$ in group B. In contrast, all the patients on therapy in group A and the $80 \%$ of those in group B were receiving 6 -mercaptopurine, compared with the $22 \%$ of patients on therapy in group $\mathrm{C}$.

Tissue DNA determination. The results of rectal biopsy DNA content are shown in Figure 1. In CD groups A and B, the mean values were $0.10 \pm 0.03$ and $0.09 \pm 0.04 \mathrm{mg} / \mathrm{mg}$ tissue, respectively. In group $\mathrm{C}$, the mean value was $0.19 \pm 0.12$ $\mathrm{mg} / \mathrm{mg}$ tissue, whereas the control group's mean value was $0.12 \pm 0.06 \mathrm{mg} / \mathrm{mg}$ tissue. No statistical differences were noted between the four groups.

Tissue cytokine levels. The rectal mucosal cytokine profiles in the three $\mathrm{CD}$ and control groups are illustrated in Figure 2, $A$ and $B$. IL-2R $\alpha$ mean values were significantly increased in all active $\mathrm{CD}$ groups (A and $\mathrm{B}$ ), with the highest levels seen in the most severely affected Group A (405 $\pm 87 \mathrm{pg} / \mathrm{mg}$ DNA). In the $\mathrm{CD}$ group $\mathrm{B}$, with mild to moderate activity, IL-2R $\alpha$

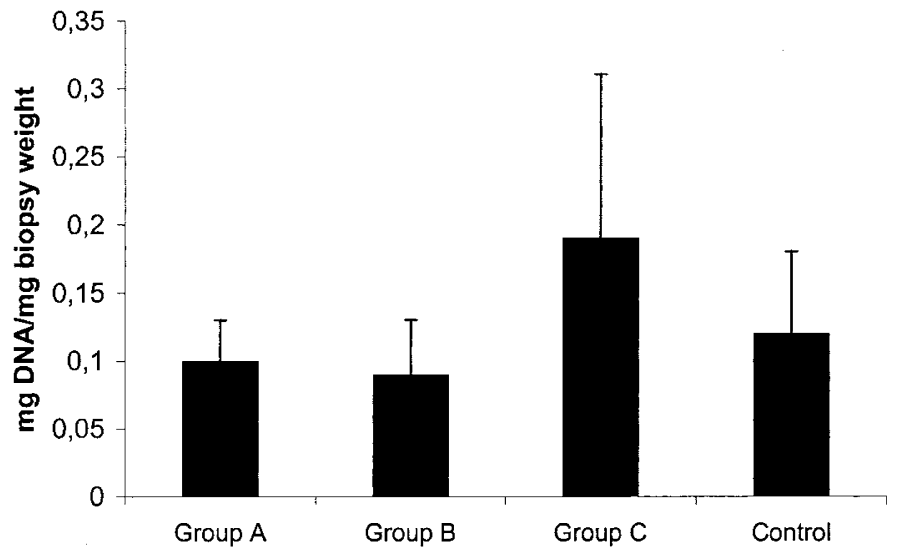

Figure 1. DNA tissue levels are shown for each CD group, based on disease severity: group A (severely active), B (mild-moderately active), and C (quiescent). No statistical differences were found between the control group and the three $\mathrm{CD}$ groups. Each bar represents the mean $\pm \mathrm{SD}$ of each group.

levels $(159 \pm 31 \mathrm{pg} / \mathrm{mg}$ DNA) were also higher than in the quiescent and control groups, but was significantly less than group A. The IL-2R $\alpha$ levels in the quiescent $\mathrm{CD}$ group $\mathrm{C}$ were not different from controls $(33 \pm 15$ versus $39 \pm 20 \mathrm{pg} / \mathrm{mg}$ DNA, respectively).

IL-15 results were quite similar in groups $\mathrm{A}$ and $\mathrm{B}$, with the highest mean tissue values observed $(0.69 \pm 0.16$ and $0.72 \pm$ $0.31 \mathrm{pg} / \mathrm{mg}$ DNA, respectively). These values were both significantly higher $(p<0.05)$ than those observed in the quiescent $\mathrm{CD}$ and control groups $(0.28 \pm 0.21$ versus $0.28 \pm 0.14$ $\mathrm{pg} / \mathrm{mg}$ DNA, respectively).

IFN- $\alpha$ levels were consistently below the detection limit of the assay for all patients' rectal specimens. Thus, statistically significant differences were observed between groups A, B, and $\mathrm{C}$ for IL-2R $\alpha(P<0.001)$, as well as IL-15, which was significantly higher in groups $\mathrm{A}$ and $\mathrm{B}$, compared with group $\mathrm{C}$ and the control group $(p<0.05)$.

Influence of medical treatment. We also examined the effect of therapy on tissue cytokine profiles (Table 2). The mean values of IL-2R $\alpha$ levels for treated $(n=5)$ and nontreated $(n=9)$ patients in group B were $167 \pm 38$ and $154 \pm$ $30 \mathrm{pg} / \mathrm{mg}$ DNA, respectively. In group C, IL-2R $\alpha$ levels for treated $(n=18)$ and nontreated $(n=5)$ patients were $29 \pm 14$ and $48 \pm 18 \mathrm{pg} / \mathrm{mg}$ DNA. No significant statistical differences were observed. For IL-15, the mean values for treated and nontreated patients in group B were $0.70 \pm 0.47$ and $0.65 \pm$ $0.15 \mathrm{pg} / \mathrm{mg}$ DNA, respectively. In group C, IL-15 levels for treated and nontreated patients were $0.30 \pm 0.17$ and $0.22 \pm$ $0.12 \mathrm{pg} / \mathrm{mg}$ DNA, respectively. No statistical significant differences were found.

Table 1. CD patients grouped according to clinical and histopathological disease severity

\begin{tabular}{|c|c|c|c|c|c|c|c|}
\hline & \multicolumn{2}{|c|}{$\begin{array}{c}\text { Group A: severe CD } \\
(n=3)\end{array}$} & \multicolumn{2}{|c|}{$\begin{array}{l}\text { Group B: mild to } \\
\text { moderate } \mathrm{CD}(n=14)\end{array}$} & \multicolumn{2}{|c|}{$\begin{array}{c}\text { Group C: quiescent } \\
\text { CD }(n=23) \\
\end{array}$} & \multirow[b]{2}{*}{$p$ Value } \\
\hline & Score & $\mathrm{SD}$ & Score & $\mathrm{SD}$ & Score & $\mathrm{SD}$ & \\
\hline Van Hees index & 232 & 18 & 198 & 37 & 163 & 40 & 0.05 vs $\mathrm{C}$ \\
\hline Colonic histopathologic score & 10 & 4 & 5 & 4 & 6 & 5 & NS \\
\hline Rectal histopathologic score & 13 & 2 & 2 & 3 & 2 & 4 & 0.001 vs $\mathrm{B}, \mathrm{C}$ \\
\hline
\end{tabular}




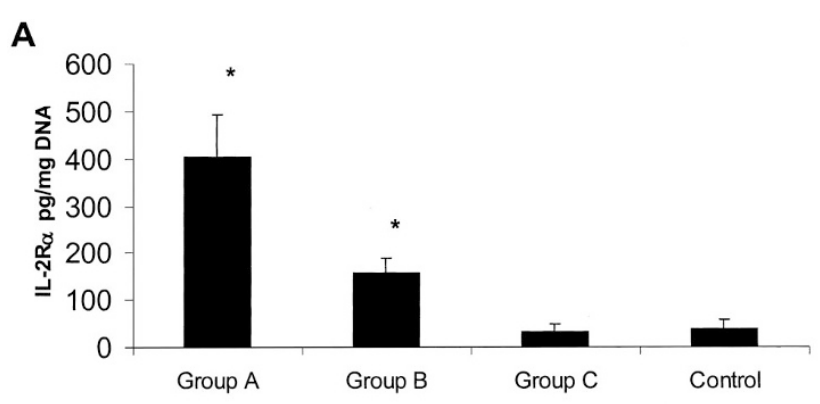

B

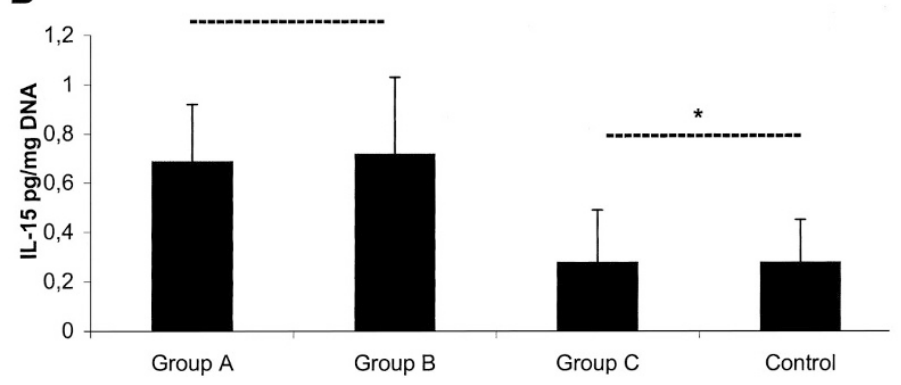

Figure 2. Colonic tissue cytokine profile in $\mathrm{CD}$ patient groups according to disease severity. (A) IL-2 $\alpha \mathrm{R}$ tissue levels are shown for biopsy homogenates. Differences between CD group A (severely active), B (mild-moderately active), and C (quiescent) are significant $(p<0.001)$. No differences were found between the control group and group C. (B) IL-15 tissue levels are shown for biopsy homogenates. Significant differences were found between groups A and $\mathrm{B}$ in comparison with group $\mathrm{C}$ and the control group $(p<0.05)$. Each bar represents the mean $\pm \mathrm{SD}$ of each group. Asterisks indicate significant differences between groups. Statistical evaluation was performed using a one-way ANOVA for nonparametric data with Tukey and Scheffé tests.

Table 2. Effect of therapy on tissue cytokine profiles

\begin{tabular}{lccccc}
\hline & $\begin{array}{c}\text { Group B (mild to } \\
\text { moderately active) }\end{array}$ & & \multicolumn{2}{c}{$\begin{array}{c}\text { Group C (quiescent } \\
\text { disease) }\end{array}$} \\
\cline { 2 - 3 } \cline { 5 - 6 } & DNA (pg/mg) & SD & & DNA (pg/mg) & SD \\
\hline With drug therapy & 167 & 38 & & 29 & 14 \\
$\quad$ IL-2R $\alpha$ & 0.70 & 0.47 & & 0.30 & 0.17 \\
IL-15 & 154 & 30 & & 48 & 18 \\
Without drug therapy & 0.65 & 0.15 & & 0.22 & 0.12 \\
$\quad$ IL-2R $\alpha$ & & & & \\
IL-15 & & & & & \\
\hline
\end{tabular}

Correlation between clinical activity and mucosal cytokine data. The association between IL-2R $\alpha$ and IL-15 with the values of Van Hees clinical index for each CD group is shown in Figure 3. A linear correlation $(r=0.98)$ was observed for IL-2R $\alpha$ and the Van Hees index. Higher IL-15 levels were observed for increased disease activity in the Van Hees range of 200 , after which a plateau was reached.

\section{DISCUSSION}

Diverse criteria for ascertaining clinical-pathologic disease activity have been used to delineate the aberrant immune response at various stages of CD (40). However, there is a lack of correlation between clinical parameters of remission and endoscopic remission, as evidenced by the large number of clinically inactive patients with mucosal lesions visible endoscopically $(41,42)$. Thus, correlations between bioclinical
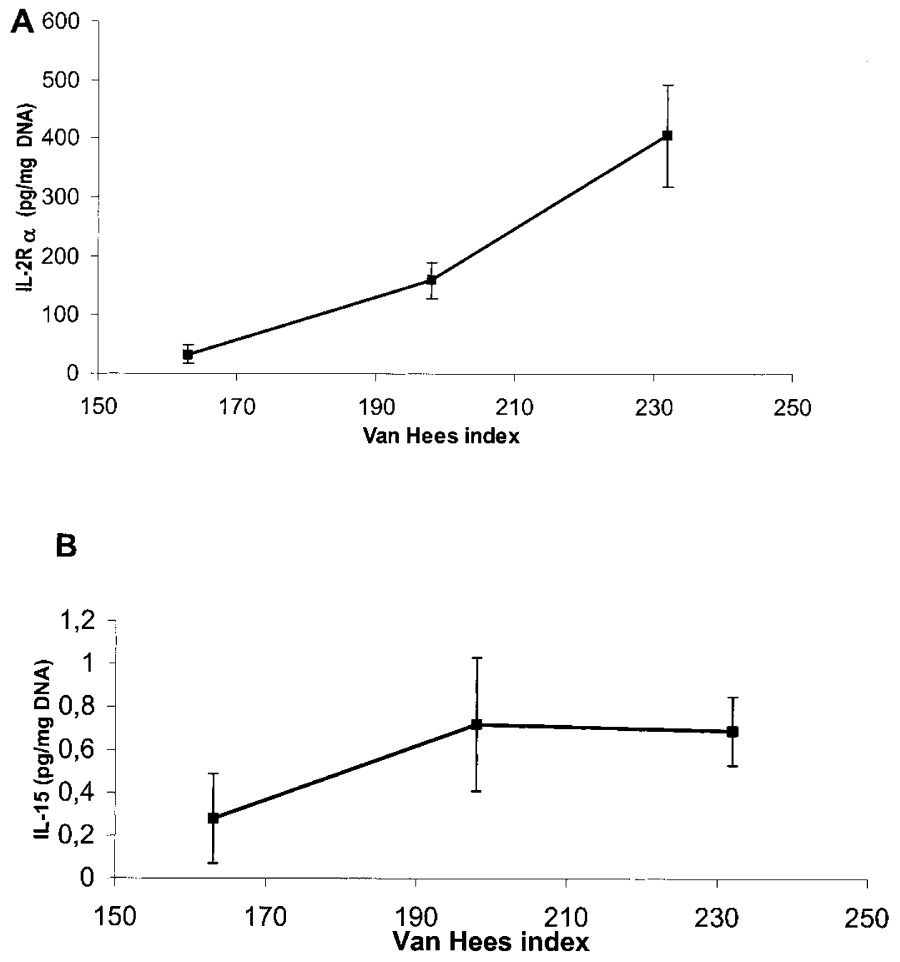

Figure 3. Correlation between clinical disease activity, expressed by Van Hees index, with cytokine tissue levels in $\mathrm{CD}$ patient groups: group $\mathrm{A}$ (severely active), B (mild-moderately active), and C (quiescent). (A) IL-2 $\alpha \mathrm{R}$ mean tissue levels $\pm \mathrm{SD}$ vs Van Hees index mean value for each CD group. A linear correlation $(r=0.98)$ was found. $(B)$ IL-15 mean tissue levels \pm SD vs Van Hees index mean values for each CD group. An increase in IL-15 tissue levels was observed between Van Hees scores of 170 and 200, above which IL-15 tissue levels reached a plateau.

activity indices and mucosal cytokine levels have been difficult to establish.

In this study, CD patients were classified into three groups, based on the severity of their disease activity, using a detailed, semiquantitative categorization system that evaluates both clinical as well as histopathological criteria (Table 1). The two clinical indices used include the Harvey Bradshaw score, a simple symptom-based clinical index without laboratory criteria. The other is the Van Hees index, which includes six clinical variables and two standard laboratory criteria of inflammation. The Van Hees index has been shown to classify patients similarly to the pediatric CD activity index (PCDAI) (43). The PCDAI requires a more detailed journal of symptoms collected prospectively. This was not feasible for this study, which relied on colonoscopy to recruit potential subjects. The Harvey Bradshaw score only differentiated between severely active and quiescent disease. On the other hand, the Van Hees index more readily differentiates between severe, moderate, and quiescent activity profiles. Our results revealed that the pathologic analysis was less sensitive to differentiate between mild-moderate and quiescent $\mathrm{CD}$ groups, compared with the tissue cytokine levels, particularly for IL-2R $\alpha$ levels.

In this study, we elected to express tissue cytokine levels in terms of the DNA content of each specimen, rather than biopsy weight or protein content. In preliminary studies, the latter values were hampered by confounding elements in the extra- 
cellular matrix and the presence of edema, yielding inconsistent values in the presence of variable degrees of inflammation. We observed that tissue DNA is a more constant indicator of cell mass, compared with dry weight and tissue protein (preliminary data not shown). This is important given that IL-2R $\alpha$ is a transmembrane protein such that its distribution and amount are restricted to the membrane surface and finally to the number of cells present. Figure 1 illustrates the DNA quantitation in the three $\mathrm{CD}$ and control groups, expressed in terms of biopsy weight. All groups had similar results, supporting the expression of mucosal cytokine content in terms of DNA, as reported herein.

We found that elevated histologic scores of inflammation (group A) correlated very highly with increased IL-2R $\alpha$ tissue levels. Control biopsies were found to have low, measurable amounts of IL-2R $\alpha$, reflecting the physiologic state of immune activation in the mucosa. These results are consistent with previous studies $(6,12)$. Most notable in the present study was the strong linear correlation $(r=0.98)$ between tissue IL-2R $\alpha$ levels and the Van Hees index (Fig. $3 A$ ). In previous reports, the highest correlation observed between IL-2R $\alpha$ levels and a clinical index $(r=0.72)$ was obtained with serum samples in CD patients and the Harvey Bradshaw index (8). Methodological differences in the homogenization procedure used and expression of the cytokine results in terms of tissue DNA likely explain the very high correlation observed in our study. IL$2 \mathrm{R} \alpha$ tissue levels of treated and untreated patients in groups B and $\mathrm{C}$, respectively, were not different (Table 2). Overall, the data thus suggest that drug therapy did not influence tissue IL-2R $\alpha$ levels, but rather that increased levels are related to the presence of active tissue inflammation. However, biopsies would need to be analyzed prospectively, before and after treatment, to resolve this issue.

IL-15 is a pro-inflammatory cytokine with numerous key effects on the immune response. However, difficulty in detecting IL-15 protein has also been described in supernatants of cells that express the mRNA because of the strong inhibitory posttranscriptional control at the level of mRNA translation (44). In the present study, we detected IL-15 tissue levels in rectal biopsies using a high-sensitivity ELISA assay. We observed that IL-15 levels were 2-fold higher in severe and mild-moderate $\mathrm{CD}$ tissue, in comparison with tissue from the controls and quiescent $\mathrm{CD}$ groups (Fig. $2 B$ ). These results are in agreement with the reports of Kirman and Nielsen (20) and Liu et al. (21), where a low percentage of PBMC and lamina propria macrophages from normal and quiescent adult $\mathrm{CD}$ patients were IL-15+, in comparison with a higher percentage in moderate and severely active CD. Also, IL-15 tissue levels of treated and untreated patients in group B and $\mathrm{C}$ were similar (Table 2), again suggesting that IL-15 tissue levels are nondrug-therapy dependant.

We found also that IL-15 and IL-2R $\alpha$ tissue levels did not increase in the same proportion when comparing groups with different degrees of severity of inflammation. IL-15 levels were similar in the severe and mild-moderate groups, whereas IL$2 \mathrm{R} \alpha$ levels increased linearly with the Van Hees clinical index of CD (Fig. 3). It is conceivable that IL-15 plays an as yet undetermined secondary role in the pathogenesis of inflamma- tion in pediatric $\mathrm{CD}$ patients, compared with other key proinflammatory cytokines such as IL- $1 \beta$, tumor necrosis factor- $\alpha, \gamma$-IFN, or IL-6 (45-47). More information is needed to clarify the immunoregulatory processes involved in the overexpression of IL-15 and its role in the inflammatory response in IBD.

A functional role of increased levels of IL-15 in CD inflamed tissue might be attributable to viral infections. IL-15 was reported to be secreted in herpes virus-infected PBMC $(24,25)$, and herpes virus has been reported to be associated with IBD. Also, high serum levels of IFN- $\alpha$ on samples from children with viral illness have been reported (48) and common transcriptional control regions for IL-15 and IFN- $2 \alpha$ have been described. Therefore, we hypothesized that $\mathrm{CD}$ patients with excessive IL-15 levels might also have increased IFN- $\alpha$ production, suggesting that a concomitant active viral infection was present. However, IFN- $\alpha$ levels were not detected in any of our CD patient specimens. Otherwise, the number of samples is too small to speculate about the role of IFN- $\alpha$ in the pathogenesis of $\mathrm{CD}$, but we would suggest that this antiviral cytokine is not likely related to IL-15 overexpression.

Despite the reliance on assays of protein levels of cytokines alone, and the limited number of patients, especially for group A, our results clearly show that IL-2R $\alpha$ tissue levels and clinical disease activity are linearly correlated in pediatric $\mathrm{CD}$ patients. IL-15 is also overexpressed in inflamed CD tissue. However, the lack of a parallel elevation of IFN- $\alpha$ does not support a role for viral induction of IL-15 in inflamed CD tissue. More direct approaches, using PCR methodology, are currently underway in our laboratory to search for viruses as a cause of disease initiation or relapse in pediatric CD.

Acknowledgments. The authors thank the members of the Pediatric Gastroenterology Service for their assistance in the recruitment of patients and providing biopsy specimens.

\section{REFERENCES}

1. Watts DA, Satsangi J 2002 The genetic jigsaw of inflammatory bowel disease. Gut 50(suppl III):iii31-iii36

2. Fiocchi C 1998 Inflammatory bowel disease: etiology and pathogenesis. Gastroenterology 115:182-205

3. Duff GW 1989 Peptide regulatory factors in non-malignant disease. Lancet 1:1432

4. Choy M, Walker-Smith J, Williams C, MacDonald T 1990 Differential expression of CD 25 (interleukin-2 receptor) on lamina propria $T$ cells and macrophages in the intestinal lesions in Crohn's disease and ulcerative colitis. Gut 31:1365-1370

5. Crabtree JE, Juby LD, Heatley RV, Lobo AJ, Bullimore DW, Axon ATR 1990 Soluble interleukin-2 receptor in Crohn's disease: relation of serum concentrations to disease activity. Gut 31:1033-1036

6. Mahida YR, Gallagher A, Kurlak L, Hawkey CJ 1990 Plasma and tissue interleukin-2 receptor levels in inflammatory bowel disease. Clin Exp Immunol 82:75-80

7. Mueller Ch, Knoflach P, Zielinski CC 1990 T-cell activation in Crohn's disease. Gastroenterology 98:639-646

8. Williams A, Symons J, Watchet K, Duff GW 1992 Soluble interleukin-2 receptor and disease activity in Crohn's disease. J Autoimmun 5:251-259

9. Schurmann G, Betzler M, Post S, Herfarth CH, Meuer S 1992 Soluble interleukin-2 receptor, interleukin-6 and interleukin- $1 \beta$ in patients with Crohn's disease and ulcerative colitis: preoperative levels and postoperative changes of serum concentrations. Digestion 51:51-59

10. Kirman I, Nielsen OH, Kjaersgaard E, Brynskov J 1995 Interleukin-2 receptor $\alpha$ and $\beta$ chain expression by circulating $\alpha \beta$ and $\gamma \delta$ T cells in inflammatory bowel disease. Dig Dis Sci 40:291-295

11. Louis E, Belaiche J, Van Kemseke C, Schaaf N, Mahieu P, Mary JY 1995 Soluble interleukin-2 receptor in Crohn's disease. Assessment of disease activity and prediction of relapse. Dig Dis Sci 40:1750-1756

12. Brynskov J, Tvede N, Andersen CB, Vilien M 1992 Increased concentrations of interleukin $1 \beta$, interleukin-2, and soluble interleukin-2 receptors in endoscopical mucosal biopsy specimens with active inflammatory bowel disease. Gut 33:55-58 
13. Matsuura T, West G, Youngman K, Klein J, Fiocchi C 1993 Immune activation genes in inflammatory bowel disease. Gastroenterology 104:448-458

14. Fehniger T, Caligiuri M 2001 Interleukin 15: biology and relevance to human disease. Blood 97:14-32

15. Grabstein KH, Eisenman J, Shanebeck K, Rauch C, Srinivasan S, Fung V, Beers C, Richardson J, Schoenborn MA, Ahdieh M, Johnson L, Alderson M, Watson J, Anderson D, Giri J 1994 Cloning of a T cell growth factor that interacts with the $\beta$ chain of the interleukin-2 receptor. Science 264:965-968

16. Carson WE, Ross ME, Baiocchi RA, Marien MJ, Boiani N, Grabstein K, Caligiuri MA 1995 Endogenous production of interleukin 15 by activated human monocytes is critical for optimal production of interferon- $\gamma$ by natural killer cells in vitro. J Clin Invest 96:2578-2582

17. Doherty TM, Seder RA, Sher A 1996 Induction and regulation of IL-15 expression in murine macrophages. J Immunol 156:735-741

18. Reinecker HC, MacDermott RP, Mirau S, Dignass A, Podolsky K 1996 Intestina epithelial cells both express and respond to interleukin 15. Gastroenterology 111:1706-1713

19. Tagaya Y, Bamford RN, DeFilippis AP, Waldmann TA 1996 IL-15 a pleiotropic cytokine with diverse receptor/signaling pathways whose expression is controlled at multiple levels. Immunity 4:329-336

20. Kirman I, Nielsen OH 1996 Increased numbers of interleukin-15-expressing cells in active ulcerative colitis. Am J Gastroenterol 91:1789-1794

21. Liu Z, Geboes K, Colpaert S, Haens G, Rutgeerts P, Ceuppens J 2000 IL-15 is highly expressed in inflammatory bowel disease and regulates local $\mathrm{T}$ cell-dependent cytokine production. J Immunol 164:3608-3615

22. Sakai T, Kusugami K, Nishimura H, Ando T, Yamaguchi T, Ohsuga M, Ina K Enomoto A, Kimura Y, Yoshikai Y 1998 Interleukin 15 activity in the rectal mucosa of inflammatory bowel disease. Gastroenterology 114:1237-1243

23. Vainer B, Nielsen OH, Hendel J, Horn T, Kirman I 2000 Colonic expression and synthesis of interleukin 13 and interleukin 15 in inflammatory bowel disease. Cytokine 12:1531-1536

24. Flamand L, Stefanescu I, Menezes J 1996 Human herpesvirus-6 enhances natural killer cell cytotoxicity via IL-15. J Clin Invest 97:1373-1381

25. Fawaz L, Sharif-Askari E, Menezes J 1999 Up-regulation of NK cytotoxic activity via IL-15 induction by different viruses: a comparative study. J Immunol 163:4473-4480

26. Guidotti L, Chisari F 2001 Noncytolytic control of viral infections by the innate and adaptative immune response. Annu Rev Immunol 19:65-91

27. Le Page C, Genin P, Baines MG, Hiscott J 2000 Interferon activation and innate immunity. Rev Immunogenet 2:374-386

28. Waldman T, Tagaya Y 1999 The multifaceted regulation of IL-15 expression and the role of this cytokine in NK cell differentiation and host response to intracellula pathogens. Annu Rev Immunol 17:19-49

29. Balfour S 1995 Microbial agents in the pathogenesis, differential diagnosis, and complications of inflammatory bowel diseases. In: Blaser M, Smith P, Ravdin J, Greenberg H, Guerrant R (eds) Infections of the Gastrointestinal Tract. Raven Press Ltd, New York, pp 435-458

30. Cottone M, Pietrosi G, Martorana G, Casa A, Pecoraro G, Oliva L, Orlando A, Rosselli M, Rizzo A, Pagliaro L 2001 Prevalence of cytomegalovirus infection in severe refractory ulcerative and Crohn's colitis. Am J Gastroenterol 96:773-775

31. Wakefield A, Fox J, Sawyerr A, Taylor JE, Sweenie CH, Smith M, Emery VC, Hudson M, Tedder RS, Pounder RE 1992 Detection of herpesvirus DNA in the large intestine of patients with ulcerative colitis and Crohn's disease using the nested polymerase chain reaction. J Med Virol 38:183-190

32. Spieker T, Herbst H 2000 Distribution and phenotype of Epstein-Bar virus-infected cells in inflammatory bowel disease. Am J Pathol 157:51-57

33. Yanai H, Shimizu N, Nagasaki S, Mitani N, Okita K 1999 Epstein-Barr virus infection of the colon with inflammatory bowel disease. Am J Gastroenterology 94:1582-1586

34. Wakefield A, Pittilo R, Sim R, Cosby SL, Stephenson JR, Dhillon AP, Pounder RE 1993 Evidence of persistent measles virus infection in Crohn's disease. J Med Viro 39:345-353

35. Haga Y, Funakoshi O, Kuroe K, Kanazawa K, Nakajima H, Saito H, Murata Y, Munakata A, Yoshida Y 1996 Absence of measles viral genomic sequence in intestinal tissue from Crohn's disease by nested polymerase chain reaction. Gut 38:211-215

36. Harvey RF, Bradshaw JM 1980 A simple index of Crohn's disease activity. Lancet $1 \cdot 514$

37. Van Hees P, Van Elteren PH, Van Lier HJJ, Van Tongeren JH 1980 An index of inflammatory activity in patients with Crohn's disease. Gut 21:279-286

38. Riddell RH 1997 Histopathology of ulcerative colitis. In: Allan R, Rhodes J, Hanauer S, Keighley M, Alexander-Williams J, Fazio V (eds) Inflammatory Bowel Disease, 3rd ed. Churchill-Livingstone, Edinburgh, pp 291-309

39. Goldblum J, Petras R 1997 Histopathology of Crohn's disease. In: Allan R, Rhodes J, Hanauer S, Keighley M, Alexander-Williams J, Fazio V (eds) Inflammatory Bowel Disease, 3rd ed. Churchill-Livingstone, Edinburgh, pp 311-316

40. Eliakim R, Rachmilewitz D 1997 Assessing disease activity in Crohn's disease-are we there yet? Eur J Gastroenterol Hepatol 9:929-930

41. Modigliani R, Mary J, Simon J, Cortot A, Soule JC, Gendre JP, Rene E 1990 Clinical, biological, and endoscopic picture of attacks of Crohn's disease. Gastroenterology 98:811-818

42. Rutgeerts P, Geboes K, Vantrappen G, Beyls J, Kerremans R, Hiele M 1990 Predictability of the postoperative course of Crohn's disease. Gastroenterology 99:956-963

43. Otley A, Loonen H, Parekh N, Corey M, Sherman P, Griffiths A 1999 Assessing activity of pediatric Crohn's disease: which index to use? Gastroenterology 116:527531

44. Waldmann T, Tagaya Y, Bamford R 1998 Interleukin-2, interleukin-15 and their receptors. Intern Rev Immunol 16:205-226

45. Reimund J, Wttersheim C, Dumont S, Muller C, Baumann R, Poindron P, Duclos B 1996 Mucosal inflammatory cytokine production by intestinal biopsies in patients with ulcerative colitis and Crohn's disease. J Clin Immunol 16:144-150

46. Dionne S, D Agata D, Hiscott J, Vanounou T, Seidman E 1998 Colonic explant production of IL-1 and its receptor antagonist is imbalanced in inflammatory bowe disease. Clin Exp Immunol 112:435-442

47. Dionne S, Ruemmele F, Laberge S, Seidman E; 2000 The effect of inflammation severity and of treatment on the production and release of TNF $\alpha$ by colonic explants in inflammatory bowel disease. Aliment Pharmacol Ther 14:1435-1442

48. Masuyama T, Matsuo M, Ichimaru T, Ishii K, Tsuchiya K, Hamasaki Y 2002 Possible contribution of interferon-alpha to febrile seizures in influenza. Pediatr Neurol $27: 289-292$ 